\title{
Assessment of Heavy Metals Concentration in Arsenic Contaminated Groundwater of the Chaco Plain, Argentina
}

\author{
M. Cecilia Giménez, ${ }^{1}$ Patricia S. Blanes, ${ }^{2}$ Edgar E. Buchhamer, ${ }^{1}$ \\ Rosa M. Osicka, ${ }^{1}$ Yamila Morisio, ${ }^{3}$ and Silvia S. Farías ${ }^{3}$ \\ ${ }^{1}$ Departamento Química Analítica, Universidad Nacional del Chaco Austral, Comandante Fernández 755, \\ Presidencia Roque Sáenz Peña H3700LGO, Chaco, Argentina \\ ${ }^{2}$ Área Química General, Departamento de Químico Física, Facultad de Ciencias Bioquímicas y Farmacéuticas, Instituto de Química \\ Rosario (IQUIR), CONICET-Universidad Nacional de Rosario, Suipacha 531, Rosario S2002LRK, Argentina \\ ${ }^{3}$ Gerencia Química, Comisión Nacional de Energía Atómica, Avenida General Paz 1499, San Martín B1650KNA, \\ Provincia de Buenos Aires, Argentina
}

Correspondence should be addressed to Patricia S. Blanes; blanes@iquir-conicet.gov.ar

Received 16 July 2013; Accepted 19 August 2013

Academic Editors: J. A. Jönsson, I. A. Katsoyiannis, and S. K. Kurunthachalam

Copyright (C) 2013 M. Cecilia Giménez et al. This is an open access article distributed under the Creative Commons Attribution License, which permits unrestricted use, distribution, and reproduction in any medium, provided the original work is properly cited.

The occurrence and distribution of arsenic and 23 other trace elements have been investigated in groundwater from Comandante Fernández Department in the Central region of Chaco Province, Northern Argentine. The arsenic concentrations samples ranged between 0.7 to $1990 \mu \mathrm{g} \mathrm{L}^{-1}$; $91 \%(n=45)$ exceeds the $10 \mu \mathrm{g} \mathrm{L}^{-1}$ World Health Organization (WHO) provisional standard limits for drinking water. Fluorine was detected in $31 \%$ of groundwater samples. Furthermore, there was found a significant correlation between As and $\mathrm{F}\left(r^{2}=0.50\right)$, indicating an association in the prevalence of both elements. In addition, about $78 \%, 31 \%, 16 \%$, $13 \%$, and $4.5 \%$ of groundwater samples had, respectively, $\mathrm{B}, \mathrm{Fe}, \mathrm{Al}, \mathrm{Mn}$, and $\mathrm{Sb}$ exceeding Código Alimentario Argentino (CAA) guideline values. In contrast of the previously values descript, the corresponding to $\mathrm{Cr}, \mathrm{Be}, \mathrm{Ni}, \mathrm{Pb}, \mathrm{Ag}$, $\mathrm{Se}$, and $\mathrm{Zn}$ were found below the quantification limit. The presence of As and trace elements in groundwater represents an important issue because it can cause a public health problem.

\section{Introduction}

Among known pollutants, trace elements are widely recognized as being potentially toxic to living organisms. Water contamination with heavy metal (HM) are mainly determined by natural (i.e., weathering, erosion of bed rocks, and ore deposits) [1] and anthropogenic (i.e., mining, industries, and agriculture) processes [2].

Soils and water containing high levels of arsenic and other toxic trace elements can easily contaminate plants, animals, and human beings in contact with them, as they either produce toxic effects or accumulate in plants and thereby enter animal and human food chains [3].

Certain elements like sodium $(\mathrm{Na})$, potassium $(\mathrm{K})$, calcium $(\mathrm{Ca})$, magnesium $(\mathrm{Mg})$, iron $(\mathrm{Fe})$, manganese $(\mathrm{Mn})$, copper $(\mathrm{Cu})$, cobalt $(\mathrm{Co})$, and zinc $(\mathrm{Zn})$ are essentially required by living organisms in specific concentrations but may produce toxic effects in high concentrations [2]. The main threats to human health from HM are associated with exposure to lead $(\mathrm{Pb})$, mercury $(\mathrm{Hg})$, cadmium $(\mathrm{Cd})$ and arsenic (As), which are extremely prejudicial owing to their toxicity, long persistence, and bioaccumulative nature [4]. Their toxic effects include headache, hypertension, irritability, abdominal pain, nerve damages, liver and kidney problems, sideroblastic anemia, intellectual disabilities, fatal cardiac arrest, and carcinogenesis. These metals have been extensively studied and their effects on human health regularly reviewed by international bodies such as the WHO [5].

Long-term drinking of arsenic contaminated water can cause severe skin diseases including skin cancer; lung, bladder, and kidney cancers, and perhaps other internal tumors; peripheral vascular disease; hypertension; and diabetes $[6,7]$. 


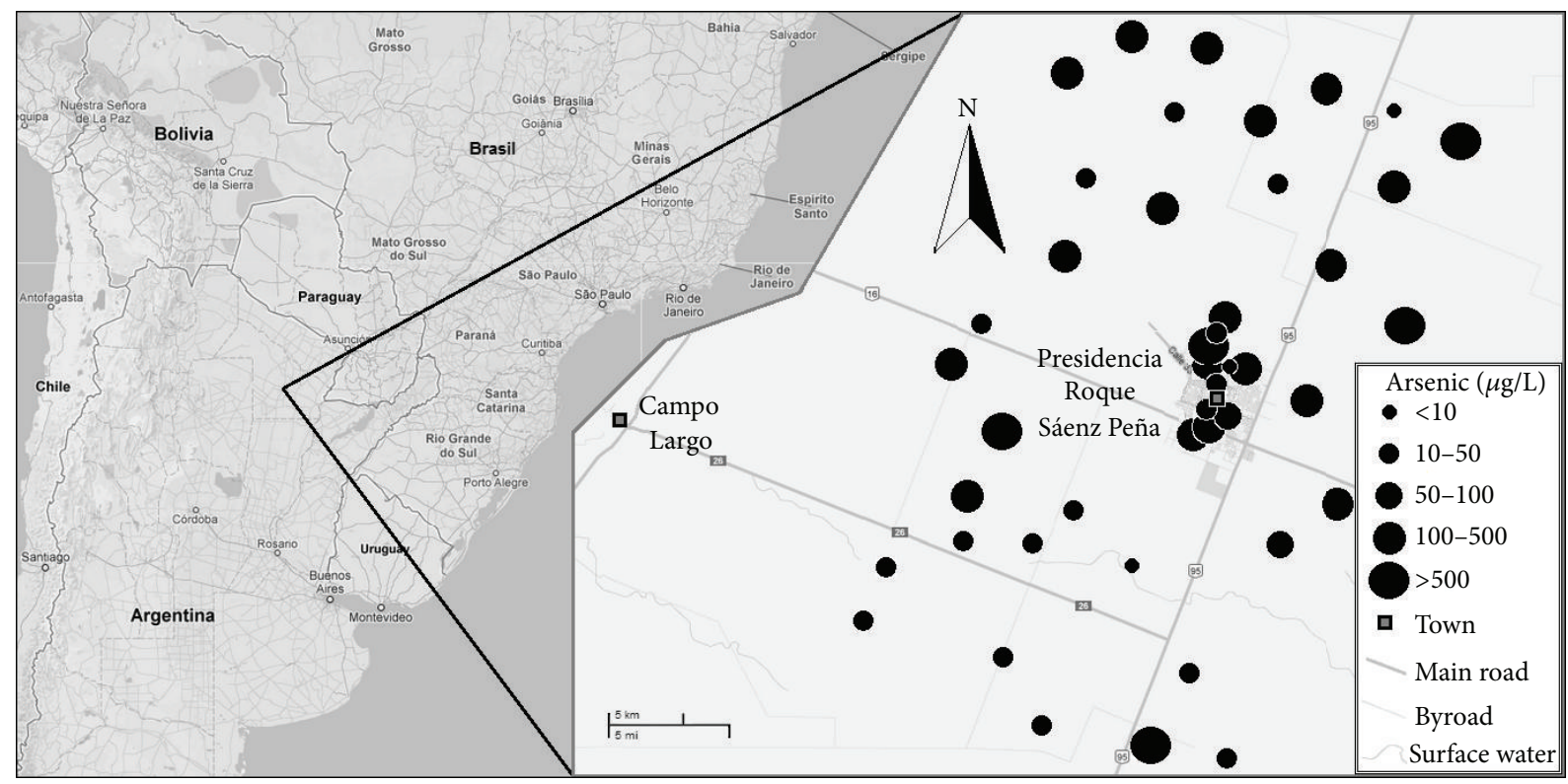

FIGURE 1: Geographical location of the study area and distribution of arsenic concentrations.

It also seems to have a negative impact on reproductive processes (infant mortality and weight of newborn babies) and cardiovascular diseases [8].

The occurrence of high concentrations of As and trace elements in drinking water has been recognized, over the past two or three decades, as a great public health concern in several parts of the world $[6,9]$. The Chaco-Pampean plain is the largest one in Latin America and one of the largest geographic units in the world affected by As-contaminated groundwater [10]. In the Chaco plain (north of the ChacoPampean plain), the major source of arsenic in groundwater is chemical weathering of the rocks, and no anthropogenic sources of contamination have been reported [11].

Particularly, it has been identified that there are elevated As concentrations in groundwater and reported in different regions of Argentina such as La Pampa [1], Buenos Aires [9], Chaco [11], Cordoba [12], Santiago del Estero [13], Santa Fe [14], and Tucumán [15] Provinces. Detailed information of the arsenic concentration in the groundwater of the CentralWest region of Chaco is available in recent publications; high fluorine $(\mathrm{F})$ and As contents in drinking waters have also been reported $[11,16]$. In addition, a positive correlation between As and $\mathrm{F}$ has been found $\left(r^{2}=0.66\right)$.

In the study area, it is necessary to carry out the research on the presence of the trace elements in groundwater which are present in concentrations higher than the WHO reference values assigned for health reasons. These elements were selected taking in view the geology of the study area and possible leaching of As and other trace metals previously reported in other areas in Chaco-Pampean plain $[14,15$, 17], like vanadium, strontium, barium, chromium, uranium, molybdenum, manganese, and selenium. The residents who lives in As-contaminated areas and consume groundwater are not only exposed to As concentrations but also to high concentration of multiple metals that can cause adverse health effects.

This paper presents an integrated study on the occurrence and the distribution of arsenic and heavy metals (HM) in groundwater in the area of Comandante Fernández in the Central region of Chaco Province, Northern Argentine. In addition, the relations between arsenic occurrence and these chemical components are discussed from a chemical point of view.

\section{Materials and Methods}

2.1. Location of the Study Area. The study area is located in the Department Comandante Fernández, Chaco Province, Northern Argentina (Figure 1). It covers an area of $1500 \mathrm{~km}^{2}$, and approximately 0.10 million population [11]. Presidencia Roque Sáenz Peña (90000 inhabitants), located between $26^{\circ} 47^{\prime} 27^{\prime \prime}$ latitudes $S$ and $60^{\circ} 26^{\prime} 29^{\prime \prime}$ longitudes $\mathrm{W}$, is the most important town where we could find an economy based on agricultural and livestock exploitation.

This area is located within the geologic province known as the Chaco Pampean [11]. The aquifers are hosted in superposed sequences of aeolian and fluvial sediments of the tertiary and quaternary ages [18]. As there are no superficial sources of groundwater, recharge of the phreatic aquifer is produced from rainfalls, while deep aquifer recharge occurs from west to east and northwest-southeast, and it is supposed to be located in the higher parts of the sub-Andean outcrops $[19,20]$.

The studied zone has a semiarid and subtropical continental type climate, characterized by sultry summers and cold winters, receiving an annual precipitation of $900 \mathrm{~mm}$, between November and March [21]. 
2.2. Sampling and Analysis. Forty-five groundwater samples were collected during May-October 2010 (a dry season), in rural and suburbs areas of the Comandante Fernández Department (Chaco Province), (Figure 1). Each sample has been collected from each tube well. Latitude and longitude of these tube wells were determined using a Garmin eTrex Legend, Global Positioning System (Garmin Ltd., UK). Specific well information, that is, the depth of the well was obtained from its owner. The sampling points were selected taking into account their spatial distribution in the area, in order to obtain an accurately representative hydrochemistry.

For all analyses, cleaning and sampling procedure involved deionized distilled water (DDW) produced by MilliQ water (Millipore Elix 5) and high-purity solvents. All glassware and polyethylene bottles were kept in $10 \%(\mathrm{v} / \mathrm{v})$ $\mathrm{HNO}_{3}$ (Merk 65\%) for 24 hours, rinsed out with DDI, and dried in a stove. All tube-wells samples were collected after $3 \mathrm{~min}$ flushing, filtered through $0.45 \mu \mathrm{m}$ membrane filters and transferred to three different polyethylene bottles to undertake different analysis. Samples for major cations analysis $\left(\mathrm{Ca}^{2+}, \mathrm{Mg}^{2+}, \mathrm{Na}^{+}\right.$, and $\left.\mathrm{K}^{+}\right)$and total As were acidified with $0.06 \mathrm{M} \mathrm{HCl}$. For trace metals analysis, samples were acidified to $\mathrm{pH}<2$ by addition of ultrapure nitric acid (Fluka). No acidified fractions were collected without headspaces in the sample bottles for measurements of anions such as $\mathrm{Cl}^{-}$, $\mathrm{SO}_{4}{ }^{2-}, \mathrm{NO}_{3}{ }^{-}, \mathrm{F}$, and alkalinity. All the samples were kept at $4^{\circ} \mathrm{C}$ until analysis.

2.3. Groundwater Analyses. The physical parameters like water temperature $(T), \mathrm{pH}$, and electrical conductivity (EC) were measured in situ by using a HANNA HI991301 Portable $\mathrm{PH} / \mathrm{EC} / \mathrm{TDS} /$ Temperature Meter. $\mathrm{Na}^{+}$and $\mathrm{K}^{+}$were determined by emission flame spectrometry (JENWAY PFP7) and $\mathrm{Ca}^{2+}$ and $\mathrm{Mg}^{2+}$ concentrations were determined by complexometric titration using ethylenediaminetetraacetic acid (0.05N EDTA). Chloride, nitrate, and fluorine ionic activity were measured with ion-selective electrodes using OAKTON CE pH/ION Mod. 510. Alkalinity was analyzed by titration method with sulfuric acid, and sulfate was measured by turbidimetric method using Spectrophotometer UV-Visible Metrolab 1700. For a better detection limit, arsenic was analyzed by hydride generation atomic absorption spectroscopy method (HGAAS) using hollow cathode lamps at $193.7 \mathrm{~nm}$ wavelength. The instrument quantification limit for this system was $5 \mu \mathrm{g} \mathrm{L}^{-1}$; an intermediate precision of less than $\pm 10 \%$ was achieved. All these analyses were performed at the Laboratories of Química Analítica, Universidad Nacional del Chaco Austral, Argentina.

Total concentrations of 23 trace elements (Ag, Al, Ba, Be, B, Cd, Co, Cr, Cu, Fe, Mn, Mo, Ni, P, Pb, S, Sb, Se, Si, Sr, Ti, $\mathrm{V}$, and $\mathrm{Zn}$ ) were determined by inductively coupled plasmaoptical emission spectrometry (ICP-OES), (PERKIN ELMER 5100 DV, axial, solid state detector, cross-flow nebulizer, associated with Scott Type chamber, and AS type auto sampler. The equipment was linearly calibrated from 1 to $100 \mu \mathrm{g} \mathrm{L}^{-1}$ with custom certified standard solution (Merck ICP Multielement Standard Solution XIII). $R^{2}$ values of calibration curves were $>0.995$, and no trend was observed in the residuals for all analyzed metals. Linearity was checked after every 10 samples using homemade control solution. If the recovery was greater than $\pm 10 \%$, the recalibration was performed for the concerned element. Accuracy of the procedure it has been tested by analyzing a certified reference material, NIST SRM 1643 c “Trace elements in water." For the studied elements, bias ranged from 2 to $7 \%$. Precision, expressed as intermediate precision was better than $9 \%$ for all analyzed elements.

2.4. Statistical Analysis. All statistical analysis of data, including maximum and minimums, means and medians, was performed using the program STATGRAPHICS 5.1 (Statistical Graphic Corporation. Manugistics Inc.; Rockville, USA). The software Rock Ware Aq.QA version 1.1.5.1 was used to construct the Piper diagrams that depicted the groundwater types.

\section{Results and Discussion}

3.1. Physicochemical Parameters. The physicochemical parameters determined in selecting 45 groundwater samples are shown in Table 1 . Well depth ranged between 5 and $220 \mathrm{~m}$, with average value of $23 \mathrm{~m}$. The $\mathrm{pH}$ values of the assorted groundwater samples varied from 6.50 to 8.94 with average value of 7.54 indicating that the waters are generally neutral to slightly alkaline. The measured water temperatures vary from 22.6 to $27.5^{\circ} \mathrm{C}$ with an average of $23.8^{\circ} \mathrm{C}$.

Major ion compositions of the analyzed groundwater samples and the major water types are shown in Table 1. High nitrate concentrations $\left(\max =200 \mathrm{mg} \mathrm{L}^{-1}\right.$ ) are present locally in some wells, probably due to anthropogenic influences, and a significant amount of $\mathrm{NO}_{3}{ }^{-}$is thought to be from evaporation. However, since the correlation between $\mathrm{NO}_{3}{ }^{-}$ and $\mathrm{Cl}^{-}$is weak $\left(r^{2}=0.04\right)$, evaporation is unlikely to be the most important cause of the high $\mathrm{NO}_{3}{ }^{-}$concentrations.

Considerable spatial variation is observed for the distributions of major cations with dominance of $\mathrm{Na}^{+}(132$ to $\left.5857 \mathrm{mg} \mathrm{L}^{-1}\right) ; \mathrm{K}^{+}\left(2.10\right.$ to $\left.110 \mathrm{mg} \mathrm{L}^{-1}\right) ; \mathrm{Ca}^{2+}(1.40$ to $\left.1100 \mathrm{mg} \mathrm{L}^{-1}\right)$, and $\mathrm{Mg}^{2+}\left(0.54\right.$ to $\left.400 \mathrm{mg} \mathrm{L}^{-1}\right)$. The same variation is observed for distribution of major anions, with dominance of $\mathrm{HCO}_{3}{ }^{-}$(median value $679 \mathrm{mg} \mathrm{L}^{-1}$ ), $\mathrm{Cl}^{-}$(median value $269 \mathrm{mg} \mathrm{L}^{-1}$ ), and $\mathrm{SO}_{4}{ }^{2-}$ (median value $209 \mathrm{mg} \mathrm{L}^{-1}$ ). Statistical parameters are shown in Table 2.

Major ion compositions plotted on a Piper diagram (Figure 2) indicate that bicarbonate and chloride were the dominant anions followed by sulfate, and that sodium was the prevalent cation. The major water types in the samples are presented in Table 1.

EC values vary from 0.69 and $24.9 \mathrm{mS} \mathrm{cm}^{-1}$ with a median value of $2.50 \mathrm{mS} \mathrm{cm}^{-1}$ and mean value of $5.27 \mathrm{mS} \mathrm{cm}^{-1}$. This may be due to contribution of $\mathrm{Na}^{+}, \mathrm{HCO}_{3}{ }^{-}, \mathrm{Cl}^{-}$, and $\mathrm{SO}_{4}{ }^{2-}$. In saline groundwater, chloride and sulfate are also important. The most saline groundwater samples are of $\mathrm{Na}-$ $\mathrm{Cl}$ type (maximum $\mathrm{Cl}^{-}$concentration $8193 \mathrm{mg} \mathrm{L}^{-1}$; Tables 1 and 2) although $\mathrm{Na}-\mathrm{SO}_{4}{ }^{2-}$ types are also important (maximum $\mathrm{SO}_{4}{ }^{2-}$ concentration $3485 \mathrm{mg} \mathrm{L}^{-1}$ ). The most significant correlations are those of chloride versus EC and sodium 
TABLE 1: Major ions composition of groundwater from the Comandante Fernández Department, Chaco.

\begin{tabular}{|c|c|c|c|c|c|c|c|c|c|c|c|c|}
\hline Sample ID & Depth (m) & $\mathrm{pH}$ & $\mathrm{EC}\left(\mathrm{mS} \mathrm{cm}^{-1}\right)$ & $\mathrm{HCO}_{3}^{-}$ & $\mathrm{Cl}^{-}$ & $\mathrm{SO}_{4}{ }^{2-}$ & $\mathrm{NO}_{3}^{-}$ & $\mathrm{Na}^{+}$ & $\mathrm{K}^{+}$ & $\mathrm{Ca}^{2+}$ & $\mathrm{Mg}^{2+}$ & Water type \\
\hline M1 & 30 & 7.53 & 2.62 & 656 & 269 & 351 & 23.1 & 644 & 7.10 & 3.54 & 1.65 & $\mathrm{Na}-\mathrm{HCO}_{3}$ \\
\hline M2 & 18 & 7.46 & 0.94 & 509 & 14.4 & 18.0 & 10.4 & 326 & 31.3 & 11.6 & 7.50 & $\mathrm{Na}-\mathrm{HCO}_{3}$ \\
\hline M3 & 13 & 8.08 & 7.07 & 860 & 510 & 3108 & nd & 1595 & 29.8 & 31.9 & 8.30 & $\mathrm{Na}-\mathrm{SO}_{4}$ \\
\hline M4 & 8 & 6.50 & 1.78 & 584 & 99.1 & 335 & 111 & 669 & 110 & 8.96 & 5.03 & $\mathrm{Na}-\mathrm{SO}_{4}$ \\
\hline M5 & 5 & 7.82 & 1.55 & 681 & 99.2 & 209 & 2.50 & 338 & 20.0 & 10.9 & 16.6 & $\mathrm{Na}-\mathrm{HCO}_{3}$ \\
\hline M6 & 20 & 7.11 & 0.83 & 408 & 21.1 & 159 & 12.2 & 132 & 13.9 & 24.5 & 11.4 & $\mathrm{Na}-\mathrm{HCO}_{3}$ \\
\hline M7 & 18 & 6.90 & 1.27 & 490 & 57.1 & 226 & 21.2 & 221 & 11.0 & 9.10 & 5.50 & $\mathrm{Na}-\mathrm{HCO}_{3}$ \\
\hline M8 & 20 & 7.68 & 2.69 & 497 & 427 & 369 & 49.3 & 1034 & 16.5 & 77.4 & 44.3 & $\mathrm{Na}-\mathrm{Cl}$ \\
\hline M9 & 13 & 8.25 & 1.34 & 895 & 45.4 & 45.0 & nd & 257 & 2.10 & 7.39 & 5.43 & $\mathrm{Na}-\mathrm{HCO}_{3}$ \\
\hline M10 & 220 & 7.98 & 21.5 & 936 & 8193 & 2070 & 12.2 & 5857 & 32.2 & 206 & 44.7 & $\mathrm{Na}-\mathrm{Cl}$ \\
\hline M11 & 50 & 7.89 & 2.44 & 135 & 135 & 480 & nd & 522 & 19.2 & 101 & 47.9 & $\mathrm{Na}-\mathrm{SO}_{4}$ \\
\hline M12 & 15 & 6.96 & 0.95 & 679 & 111 & 165 & 4.35 & 213 & 15.2 & 20.4 & 6.45 & $\mathrm{Na}-\mathrm{HCO}_{3}$ \\
\hline M13 & 12 & 7.29 & 1.36 & 722 & 140 & 107 & 2.10 & 382 & 9.10 & 1.40 & 0.54 & $\mathrm{Na}-\mathrm{HCO}_{3}$ \\
\hline M14 & 12 & 7.93 & 1.49 & 654 & 129 & 83.1 & 14.4 & 806 & 10.0 & 2.30 & 0.52 & $\mathrm{Na}-\mathrm{HCO}_{3}$ \\
\hline M15 & 12 & 7.61 & 2.37 & 769 & 512 & 412 & 107 & 531 & 17.2 & 18.9 & 12.8 & $\mathrm{Na}-\mathrm{Cl}$ \\
\hline M16 & 35 & 7.51 & 0.69 & 198 & 89.2 & 136 & 2.30 & 200 & 6.87 & 28.5 & 7.54 & $\mathrm{Na}-\mathrm{HCO}_{3}$ \\
\hline M17 & 15 & 6.84 & 4.48 & 760 & 1447 & 431 & 20.1 & 825 & 23.2 & 14.9 & 46.4 & $\mathrm{Na}-\mathrm{Cl}$ \\
\hline M18 & 8 & 6.91 & 3.36 & 448 & 1661 & 182 & 14.5 & 1161 & 12.1 & 122 & 56.9 & $\mathrm{Na}-\mathrm{Cl}$ \\
\hline M19 & 12 & 6.78 & 1.75 & 302 & 408 & 335 & 200 & 132 & 12.9 & 6.46 & 2.18 & $\mathrm{Na}-\mathrm{Cl}$ \\
\hline M20 & 13 & 7.78 & 4.41 & 751 & 1425 & 421 & 20.3 & 775 & 18.4 & 22.7 & 59.8 & $\mathrm{Na}-\mathrm{Cl}$ \\
\hline M21 & 15 & 8.28 & 8.56 & 1017 & 908 & 3485 & 27.3 & 1814 & 19.4 & 63.4 & 78.7 & $\mathrm{Na}-\mathrm{SO}_{4}$ \\
\hline M22 & 17 & 7.36 & 0.88 & 251 & 140 & 49.2 & 24.5 & 216 & 18.4 & 12.5 & 0.92 & $\mathrm{Na}-\mathrm{Cl}$ \\
\hline M23 & 10 & 7.24 & 1.59 & 980 & 28.0 & 113 & 13.4 & 309 & 16.3 & 9.37 & 3.50 & $\mathrm{Na}-\mathrm{HCO}_{3}$ \\
\hline M24 & 8 & 7.16 & 1.06 & 806 & 104 & 35.0 & 19.3 & 661 & 19.0 & 32.4 & 20.3 & $\mathrm{Na}-\mathrm{HCO}_{3}$ \\
\hline M25 & 14 & 7.31 & 23.3 & 835 & 5536 & 1486 & 19.5 & 3158 & 22.4 & 109 & 152 & $\mathrm{Na}-\mathrm{Cl}$ \\
\hline M26 & 12 & 7.95 & 1.33 & 356 & 112 & 117 & nd & 877 & 21.2 & 71.6 & 32.6 & $\mathrm{Na}-\mathrm{HCO}_{3}$ \\
\hline M27 & 50 & 7.25 & 4.18 & 651 & 571 & 190 & nd & 836 & 23.3 & 50.1 & 22.3 & $\mathrm{Na}-\mathrm{HCO}_{3}$ \\
\hline M28 & 14 & 7.88 & 9.76 & 321 & 1142 & 804 & nd & 1969 & 69.8 & 432 & 147 & $\mathrm{Na}-\mathrm{Cl}$ \\
\hline M29 & 15 & 7.06 & 5.35 & 405 & 1099 & 707 & 45.2 & 1065 & 57.7 & 319 & 120 & $\mathrm{Na}-\mathrm{Cl}$ \\
\hline M30 & 10 & 7.64 & 1.41 & 864 & 110 & 164 & 12.2 & 320 & 15.2 & 33.2 & 22.1 & $\mathrm{Na}-\mathrm{HCO}_{3}$ \\
\hline M31 & 50 & 7.76 & 3.05 & 964 & 244 & 519 & 6.50 & 563 & 7.59 & 4.57 & 2.24 & $\mathrm{Na}-\mathrm{HCO}_{3}$ \\
\hline M32 & 12 & 7.29 & 8.05 & 1868 & 1300 & 43.2 & 10.1 & 489 & 3.12 & 355 & 92.2 & $\mathrm{Na}-\mathrm{HCO}_{3}$ \\
\hline M33 & 10 & 7.26 & 5.29 & 679 & 762 & 582 & 2.30 & 747 & 19.5 & 123 & 88.4 & $\mathrm{Na}-\mathrm{Cl}$ \\
\hline M34 & 12 & 7.53 & 1.15 & 500 & 85.1 & 91.2 & 21.3 & 268 & 9.71 & 19.1 & 11.3 & $\mathrm{Na}-\mathrm{HCO}_{3}$ \\
\hline M35 & 8 & 8.17 & 2.98 & 1652 & 165 & 116 & 25.4 & 549 & 6.16 & 3.74 & 3.90 & $\mathrm{Na}-\mathrm{HCO}_{3}$ \\
\hline M36 & 10 & 7.17 & 11.8 & 1868 & 742 & 1506 & 2.25 & 2100 & 2.71 & 90.4 & 150 & $\mathrm{Na}-\mathrm{SO}_{4}$ \\
\hline M37 & 8 & 7.55 & 1.74 & 920 & 73.2 & 108 & 13.5 & 823 & 8.54 & 15.6 & 9.30 & $\mathrm{Na}-\mathrm{HCO}_{3}$ \\
\hline M38 & 20 & 8.94 & 6.33 & 214 & 1012 & 1350 & nd & 994 & 10.8 & 18.3 & 55.8 & $\mathrm{Na}-\mathrm{Cl}$ \\
\hline M39 & 15 & 7.26 & 10.0 & 463 & 2634 & 1258 & 72.1 & 1029 & 67.8 & 498 & 202 & $\mathrm{Na}-\mathrm{Cl}$ \\
\hline M40 & 52 & 7.00 & 19.4 & 764 & 4636 & 1520 & 23.4 & 200 & 54.2 & 183 & 182 & $\mathrm{Mg}-\mathrm{Cl}$ \\
\hline M41 & 65 & 8.51 & 24.9 & 817 & 5121 & 1537 & 39.4 & 2100 & 67.9 & 67.0 & 144 & $\mathrm{Na}-\mathrm{Cl}$ \\
\hline M42 & 12 & 8.92 & 1.43 & 668 & 26.0 & 35.5 & 21.2 & 244 & 11.5 & 8.06 & 3.37 & $\mathrm{Na}-\mathrm{HCO}_{3}$ \\
\hline M43 & 8 & 7.28 & 1.81 & 618 & 234 & 74.2 & 4.50 & 765 & 32.4 & 57.6 & 16.3 & $\mathrm{Na}-\mathrm{HCO}_{3}$ \\
\hline M44 & 11 & 7.07 & 2.50 & 723 & 450 & 90.1 & 56.1 & 223 & 30.3 & 132 & 64.6 & $\mathrm{Ca}-\mathrm{Cl}$ \\
\hline M45 & 12 & 6.81 & 14.4 & 298 & 5674 & 26.3 & 42.4 & 459 & 28.6 & 1100 & 400 & $\mathrm{Ca}-\mathrm{Cl}$ \\
\hline
\end{tabular}

Nd: non detected. All concentrations are expressed as $\mathrm{mg} \mathrm{L}^{-1}$. 


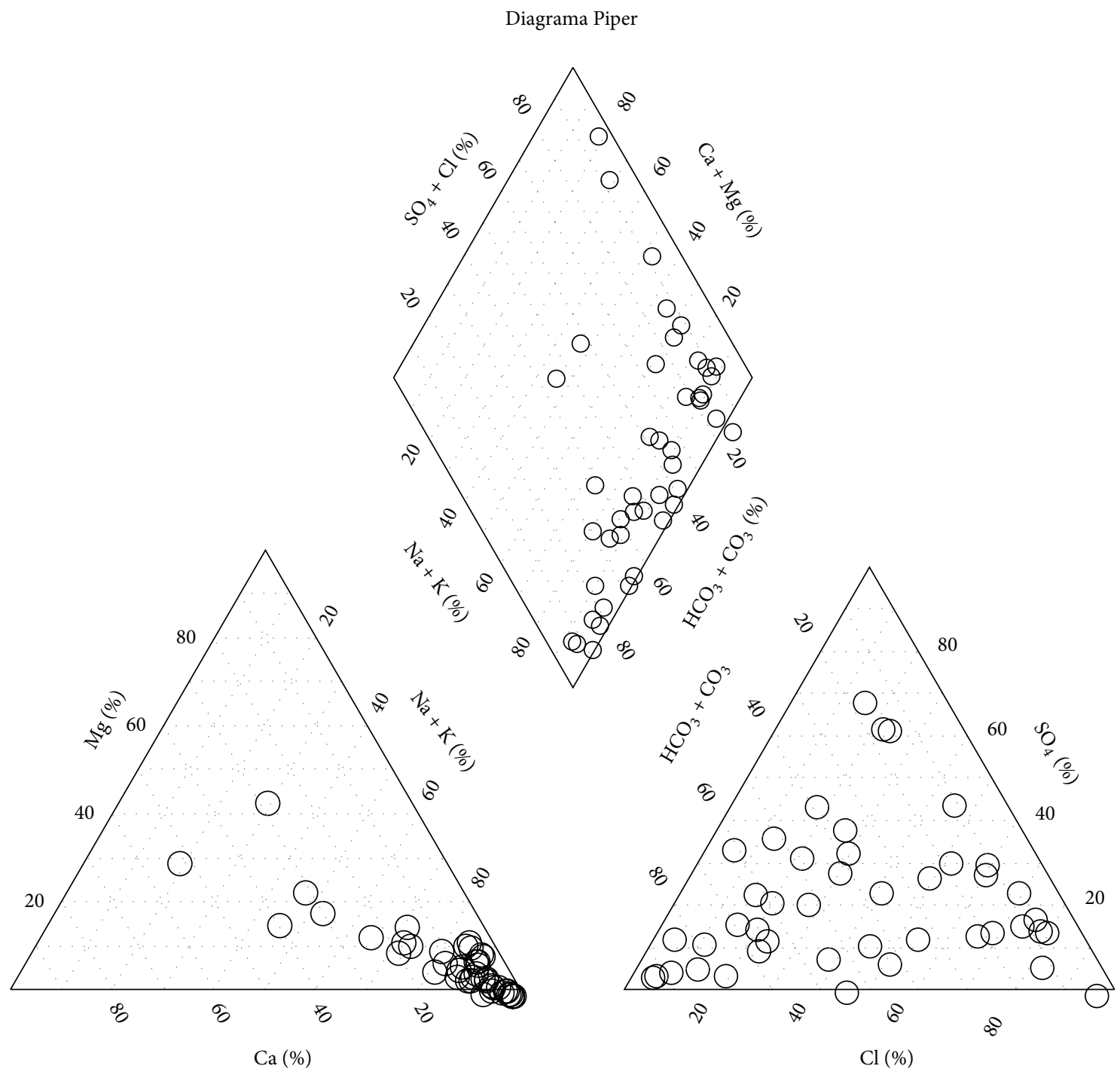

FIGURE 2: Piper diagram showing the chemical compositions of groundwater samples.

$\left(r^{2}=0.91 ; r^{2}=0.69\right)$ and sulfate versus EC and sodium $\left(r^{2}=0.62 ; r^{2}=0.61\right)$, which is related to the predominance of sodium chloride types in groundwater with higher salinity. Sodium bicarbonate waters are related generally with low salinity samples; in analyzed groundwater samples the EC shows poor correlation with $\mathrm{HCO}_{3}{ }^{-}\left(r^{2}=0.21\right)$.

Results of chemical analysis show large variations in chemical composition and also indicate the high salinity of many of the groundwater samples. According to Larroza and Fariña [19], the salinity of groundwater in the basin of the Chaco region is due to the previous existence of a shallow sea of restricted environment, which has left its salts; this geographical feature, called Paranaense Sea, has originated during the Middle and Upper Miocene. The extremely heterogeneous values of EC from groundwater could be explained by the local variation in sedimentary and hydrogeological characteristics [13]. Moreover, the evaporation in arid and semiarid zones favors the increase of salinity and alkalinity $[15,22]$.
3.2. Total Arsenic and Fluoride. Arsenic is classified as a human carcinogen (Type A) based on sufficient epidemiologic evidence linking increased mortality from liver, kidney, bladder, and lung cancers to drinking As-contaminated water [23]. The provisional guideline value recommended by the WHO [5] for this carcinogenic contaminant in drinking water is $10 \mu \mathrm{g} \mathrm{L}^{-1}$ and in Argentina this would be enforced in 2017 [24]. On the basis of this criterion, only 9\% (4/45) of groundwater source is within levels recommended for consumption; whereas about 73\% (33/45) of all analyzed samples showed As values above $50 \mu \mathrm{g} \mathrm{L}^{-1}$ (CAA) [25]. Mean concentration of total arsenic in groundwater was $213 \mu \mathrm{g} \mathrm{L}^{-1}$ and maximum was $1990 \mu \mathrm{g} \mathrm{L}^{-1}$ (Table 2). The highest As concentration was found in groundwater collected in sample M36. The presence of arsenic in the groundwater samples collected from this region of Argentina is natural; the local geology and rainfall have been shown to have major impact on the variations of As concentration in groundwater. 
TABLE 2: Statistical summary of the chemistry of groundwater (major ions and trace elements; $n=45$ ) from Comandante Fernández Department, Chaco, Northeast Argentina.

\begin{tabular}{|c|c|c|c|c|c|c|}
\hline Parameter & Mean & Median & Range & 10th percentil & 90th percentil & Standard deviation \\
\hline Depth (m) & 22.0 & 13.0 & $5.00-220$ & 8.00 & 50.0 & 33.1 \\
\hline $\mathrm{pH}$ & 7.54 & 7.51 & $6.50-8.94$ & 6.90 & 8.22 & 0.55 \\
\hline $\mathrm{EC}(\mathrm{mS} / \mathrm{cm})$ & 5.27 & 2.50 & $0.69-24.9$ & 0.99 & 13.4 & 6.28 \\
\hline $\mathrm{HCO}_{3}{ }^{-}\left(\mathrm{mg} \mathrm{L}^{-1}\right)$ & 699 & 679 & $135-1868$ & 299 & 974 & 376 \\
\hline $\mathrm{Cl}^{-}\left(\mathrm{mg} \mathrm{L}^{-1}\right)$ & 1082 & 269 & $14.4-8193$ & 50.1 & 3835 & 1832 \\
\hline $\mathrm{SO}_{4}{ }^{2-}\left(\mathrm{mg} \mathrm{L}^{-1}\right)$ & 570 & 209 & $18.0-3485$ & 43.9 & 1514 & 789 \\
\hline $\mathrm{NO}_{3}^{-}\left(\mathrm{mg} \mathrm{L}^{-1}\right)$ & 29.7 & 14 & bdl-200 & 0.03 & 53.4 & 36.1 \\
\hline $\mathrm{F}\left(\mathrm{mg} \mathrm{L}^{-1}\right)$ & 1.29 & 1.00 & $0.10-4.20$ & 0.30 & 3.08 & 1.10 \\
\hline $\mathrm{Na}^{+}\left(\mathrm{mg} \mathrm{L}^{-1}\right)$ & 875 & 644 & $132-5857$ & 214 & 1907 & 989 \\
\hline $\mathrm{K}^{+}\left(\mathrm{mg} \mathrm{L}^{-1}\right)$ & 23.6 & 18.4 & $2.10-110$ & 6.96 & 56.3 & 21.5 \\
\hline $\mathrm{Ca}^{2+}\left(\mathrm{mg} \mathrm{L}^{-1}\right)$ & 101 & 28.5 & $1.40-1100$ & 5.33 & 274 & 191 \\
\hline $\mathrm{Mg}^{2+}\left(\mathrm{mg} \mathrm{L}^{-1}\right)$ & 53.7 & 20.3 & $0.52-400$ & 2.20 & 149 & 76.2 \\
\hline $\mathrm{S}\left(\mathrm{mg} \mathrm{L}^{-1}\right)$ & 49.3 & 0.57 & $0.006-724$ & 0.06 & 125 & 130 \\
\hline $\mathrm{P}\left(\mathrm{mg} \mathrm{L}^{-1}\right)$ & 2.70 & 0.8 & $0.17-22.9$ & 0.30 & 8.26 & 4.41 \\
\hline As $\left(\mu \mathrm{gL}^{-1}\right)$ & 213 & 100 & 7-1990 & 17.0 & 500 & 347 \\
\hline $\mathrm{Al}\left(\mu \mathrm{g} \mathrm{L}^{-1}\right)$ & 561 & 99.0 & $60.0-17380$ & 60.0 & 257 & 2601 \\
\hline $\mathrm{Ba}\left(\mu \mathrm{g} \mathrm{L}^{-1}\right)$ & 122 & 14.0 & bdl-1400 & 2.00 & 135 & 211 \\
\hline $\mathrm{B}\left(\mu \mathrm{g} \mathrm{L}^{-1}\right)$ & 4020 & 1970 & $156-21910$ & 283 & 7896 & 5599 \\
\hline $\mathrm{Cd}\left(\mu \mathrm{g} \mathrm{L}^{-1}\right)$ & 2.00 & 2.00 & bdl-7.0 & 1.00 & 4.00 & 1.40 \\
\hline $\mathrm{Cu}\left(\mu \mathrm{g} \mathrm{L}^{-1}\right)$ & 23.0 & 6.00 & bdl-280 & 0.10 & 65.8 & 48.7 \\
\hline $\operatorname{Co}\left(\mu \mathrm{g} \mathrm{L}^{-1}\right)$ & 27.2 & 3.00 & bdl-280 & 1.40 & 82.6 & 6.20 \\
\hline $\mathrm{Fe}\left(\mu \mathrm{g} \mathrm{L}^{-1}\right)$ & 276 & 81.0 & bdl-2000 & 0.10 & 716 & 396 \\
\hline $\operatorname{Mn}\left(\mu \mathrm{gL}^{-1}\right)$ & 152 & 5.00 & bdl-3740 & 0.10 & 327 & 574 \\
\hline $\operatorname{Mo}\left(\mu \mathrm{g} \mathrm{L}^{-1}\right)$ & 23.9 & 21.0 & bdl-160 & 3.00 & 42.0 & 30.8 \\
\hline $\mathrm{Si}\left(\mu \mathrm{g} \mathrm{L}^{-1}\right)$ & 1057 & 150 & bdl-16570 & 0.40 & 2415 & 2803 \\
\hline $\operatorname{Sr}\left(\mu \mathrm{gL}^{-1}\right)$ & 449 & 86 & $2.00-4871$ & 15.0 & 873 & 873 \\
\hline $\operatorname{Se}\left(\mu \mathrm{gL}^{-1}\right)$ & 1.9 & 1.00 & bdl-10.0 & 0.1 & 6.60 & 2.70 \\
\hline $\mathrm{Sb}\left(\mu \mathrm{g} \mathrm{L}^{-1}\right)$ & 5.4 & 1.00 & bdl-111 & 0.10 & 9.00 & 1.7 \\
\hline $\mathrm{Ni}\left(\mu \mathrm{g} \mathrm{L}^{-1}\right)$ & 0.9 & 0.10 & bdl-10.0 & 0.10 & 3.00 & 1.90 \\
\hline $\mathrm{V}\left(\mu \mathrm{g} \mathrm{L}^{-1}\right)$ & 204 & 76.0 & bdl-2646 & 11.4 & 416 & 431 \\
\hline $\mathrm{Zn}\left(\mu \mathrm{g} \mathrm{L}^{-1}\right)$ & 83.8 & 3.00 & bdl-2813 & 0.10 & 67.0 & 487 \\
\hline
\end{tabular}

Different positive correlation were observed in groundwater between As versus $\mathrm{HCO}_{3}{ }^{-}$and $\mathrm{Na}^{+}\left(r^{2}=0.75 ; r^{2}=\right.$ $0.45)$, and a negative correlation was found between As and $\mathrm{Ca}^{2+}\left(r^{2}=-0.05\right)$. It could be assumed that As is associated with $\mathrm{Na}-\mathrm{HCO}_{3}{ }^{-}$system, related to feldspar dissolution [26]. Based on values of $\mathrm{pH}$ found in groundwater of this region of Chaco, including data reported from other sites of the region $[1,13,27]$, it can be presumed that $\mathrm{pH}$ controls As mobility.

The study made by Smedley et al. [28] reveals that highly $\mathrm{As}(\mathrm{V})$-contaminated groundwater in oxidizing environments throughout the world are characterized by high concentration of $\mathrm{HCO}_{3}{ }^{-}\left(>500 \mathrm{mg} \mathrm{L}^{-1}\right)$ and $\mathrm{SO}_{4}{ }^{2-}\left(>250 \mathrm{mg} \mathrm{L}^{-1}\right)$ and $\mathrm{pH}>7.50$. Similar geochemical conditions occur in the Chaco-Pampean plain, like in the arid regions of Santiago del Estero, Córdoba y La Pampa [13, 14, 27]. High As concentrations are common and dominated by $\mathrm{As}(\mathrm{V})$, and the groundwater have correspondingly high $\mathrm{F}$ concentrations. These general characteristic are consistent with the analyzed groundwater. However, arsenic speciation is not performed in the present study.

On the other hand, smaller quantities of fluoride ion in the order of $1 \mathrm{mg} \mathrm{L}^{-1}$ in ingested water are usually considered to have a beneficial effect by lowering the rate of occurrence of dental caries. Excessive intake $\left(>1.5 \mathrm{mg} \mathrm{L}^{-1}\right)$ would results in pathological changes in teeth and bones, such as mottling of teeth or dental fluorosis, along with metabolic changes reported on soft tissues such as thyroid, reproductive organs, brain, liver, and kidneys [29].

The WHO guideline value for $\mathrm{F}$ concentration in drinking water is $1.5 \mathrm{mg} \mathrm{L}^{-1}$ [5], whereas the Código Alimentario Argentino (CCA) [25] establishes a limit that varies according to the average temperature of the place $\left(1 \mathrm{mg} \mathrm{L}^{-1}\right.$ for an average temperature of $21.5^{\circ} \mathrm{C}$ in the area under study). The distribution of $\mathrm{F}$ concentrations is heterogeneous and similar to As. A positive correlation was observed between As and F with $r^{2}=0.50$. The analyzed groundwater, 31\% (14/45) of 
the samples exceeded the WHO guideline value of $1.5 \mathrm{mg} \mathrm{L}^{-1}$ [5]. About $47 \%$ of all analyzed samples showed $F$ values above $1 \mathrm{mg} \mathrm{L}^{-1}$ recommended by CAA (Table 4). Similar correlations between As and $\mathrm{F}$ were also observed in groundwater from neighboring Santiago del Estero [13], Santa Fe [14], and Salta Provinces [30].

In the same way as arsenic, the F rich water is characterized by high concentration of $\mathrm{Na}^{+}$and low concentration of $\mathrm{Ca}^{2+}$ and $\mathrm{Mg}^{2+}\left(r^{2}=0.45 ; 0.09\right.$ and 0.16 ; resp.). Fluoride is a highly reactive element that combines with other elements in covalent and ionic bonds. It is mainly found in alkaline rocks and alkaline soils, fluorite being the principal component. Gomez et al. [27] explain that the processes that could control the low relationship between $\mathrm{F}$ and $\mathrm{Ca}^{2+}$ and the positive relationship between $\mathrm{F}$ and bicarbonate $\left(r^{2}=0.24\right)$ would be the balance equation relating calcite and fluorite when both are in contact with water.

As and other trace elements such as V, Mo, U, and minor elements such as B and $\mathrm{F}$ are presumed to have their original source in volcanic ashes originated from the volcanism in the Andes (5-25\% in the loess-type sediments of the Chaco-Pampean plain) [9]. The main components of these sediments are feldspars, quartz, volcanic glass shards, and minor amounts of muscovite and calcite. The composition of volcanic glass is typically rhyolitic, containing a high concentration of F, As, V, and B among other trace elements [28].

3.3. Other Trace Elements. A series of various trace elements, including $\mathrm{Ag}, \mathrm{Al}, \mathrm{B}, \mathrm{Ba}, \mathrm{Be}, \mathrm{Cd}, \mathrm{Co}, \mathrm{Cr}, \mathrm{Cu}, \mathrm{Fe}, \mathrm{Mn}, \mathrm{Mo}$, $\mathrm{Ni}, \mathrm{P}, \mathrm{Pb}, \mathrm{S}, \mathrm{Sb}, \mathrm{Se}, \mathrm{Si}, \mathrm{Sr}, \mathrm{Ti}, \mathrm{V}$, and $\mathrm{Zn}$ were also determined in the studied groundwater. The concentrations of target elements are summarized in Table 3. Among all 23 target analytes, concentrations exceeding the WHO recommended drinking water limits (in parentheses) were found for B $\left(2400 \mu \mathrm{g} \mathrm{L}^{-1}\right), \mathrm{Ba}\left(700 \mu \mathrm{g} \mathrm{L}^{-1}\right), \mathrm{Cd}\left(3 \mu \mathrm{g} \mathrm{L}^{-1}\right)$, and $\mathrm{Sb}$ $\left(20 \mu \mathrm{g} \mathrm{L}^{-1}\right)$. Table 4 shows the percentage of groundwater samples exceeding these WHO and CAA elemental concentration guidelines. On the other hand, concentrations of $\mathrm{Sn}$, $\mathrm{Co}, \mathrm{Cu}, \mathrm{Ni}, \mathrm{S}, \mathrm{Se}, \mathrm{Sr}, \mathrm{V}$, and $\mathrm{Zn}$ were very low. Silver, beryllium, chrome, selenium, lead and titanium are not includ in Tables 2 and 3 because these elements were never found above respective quantification limits.

From the samples investigated, only one (M45) showed elevated value of barium $\left(1400 \mu \mathrm{g} \mathrm{L}^{-1}\right)$ than in the WHO drinking water guideline $\left(700 \mu \mathrm{g} \mathrm{L}^{-1}\right)$ with an average value of $122 \mu \mathrm{g} \mathrm{L}^{-1}$ (Table 2).

In small quantities, $\mathrm{B}$ is essential for healthy bones, joint function, and the metabolism of steroidal hormones. Boron deficiency seems to affect calcium and magnesium metabolism and affects the composition, structure, and strength of bone [31]. The concentrations of boron (B) ranged from 1560 to $21910 \mu \mathrm{g} \mathrm{L}^{-1}$ with an average of $4020 \mu \mathrm{g} \mathrm{L}^{-1}$ (Table 2). Boron concentration in the $44 \%(20 / 45)$ of the samples exceeds the WHO and 78\% (35/45) of the samples exceeds the CAA standard limits for drinking water (Table 4). The highest concentration of boron was observed in sample M40 which is associated with the largest value of EC $\left(19371 \mu \mathrm{S} \mathrm{cm}^{-1}\right)$. In general, the presence of boron in groundwater depends on its salinity (represented as EC), such that it increases with increasing salinity [32]. In this study, a positive correlation between EC and boron $\left(r^{2}=0.64\right)$ suggests that boron might be associated with the salinity of these samples. Hence, the salinity mainly reflects the variation of $\mathrm{Cl}^{-}$concentration, with a strong linear correlation $\left(r^{2}=0.91\right)$ between $\mathrm{EC}$ and $\mathrm{Cl}^{-}$, suggesting that the increase of $\mathrm{Cl}^{-}$concentration contributes to increase in $\mathrm{EC}$ value. The hydraulic conductivity, salinity, type of clay sediments, $\mathrm{pH}$ and temperature are the crucial factors that determine boron mobility in the groundwater system [32]. Boron was strongly correlated with $\mathrm{Na}^{+}, \mathrm{K}^{+}, \mathrm{Mg}^{2+}, \mathrm{Cl}^{-}, \mathrm{SO}_{4}{ }^{2-}, \mathrm{HCO}_{3}{ }^{-}$, and As, probably due to their common origin. The correlation between $\mathrm{B}$ and As is often observed in groundwater $[1,13]$.

Our results indicate that approximately $31 \%$ of the groundwater samples tested exceeded the CAA criteria of $300 \mu \mathrm{g} \mathrm{L}^{-1}$ for total Fe in drinking water. The highest total Fe concentration $\left(2000 \mu \mathrm{g} \mathrm{L}^{-1}\right)$ appeared in sample M38. In general, Fe concentration was low in the studied groundwater samples; only fourteen samples had higher Fe with a mean value of $276 \mu \mathrm{g} \mathrm{L}^{-1}$ and median value of $81 \mu \mathrm{g} \mathrm{L}^{-1}$. On the other hand, weaker correlation is observed between Fe and As in groundwater $\left(r^{2}=0.17\right)$. Moreover, almost all groundwater with high Fe concentration $\left(>300 \mu \mathrm{g} \mathrm{L}^{-1}\right)$ contained total As concentration over $10 \mu \mathrm{g} \mathrm{L}^{-1}$ (Table 3).

The concentration of dissolved $\mathrm{Al}$ varied between 60.0 to $17380 \mu \mathrm{g} \mathrm{L}^{-1}$ with a mean value of $561 \mu \mathrm{g} \mathrm{L}^{-1}$ (Table 2). A $16 \%(7 / 45)$ exceeded the $200 \mu \mathrm{g} \mathrm{L}^{-1}$ CAA drinking water guideline. However, the mean concentration of $\mathrm{Al}$ decreases significantly down to $178 \mu \mathrm{g} \mathrm{L}^{-1}$ (median $98.5 \mu \mathrm{g} \mathrm{L}^{-1}$ ), if the anomalous of sample M24 is excluded. Also Aluminum shows no correlation with As $\left(r^{2}=-0.06\right)$.

Manganese exceeded the $100 \mu \mathrm{g} \mathrm{L}^{-1} \mathrm{CAA}$ drinking water guideline value in 13\% (6/45) of the samples (Tables 3 and 4). The highest $\mathrm{Mn}$ concentration $\left(3740 \mu \mathrm{g} \mathrm{L}^{-1}\right)$ was found in sample M32. However, the mean concentration of Mn decreases significantly from 152 to $70.0 \mu \mathrm{gL}^{-1}$ (median $\left.5.00 \mu \mathrm{g} \mathrm{L}^{-1}\right)$, if the anomalous value of this sample is excluded. Manganese shows no correlation with As $\left(r^{2}=-0.07\right)$. $\mathrm{Mn}$ is known as an essential element for human survival, serves as a catalyst and cofactor in many enzymatic processes involved in the synthesis of fatty acids and cholesterol. The chronic ingestion of $\mathrm{Mn}$ in drinking water is associated with neurologic damage [33]. Moreover, manganese is a known mutagen [34].

Many samples have $\mathrm{Fe}, \mathrm{Al}$, and $\mathrm{Mn}$ concentrations below detection limits and most have below CAA guideline value. However, concentrations are higher in a few samples (Table 2). Smedley et al. [1] suggest that at the $\mathrm{pH}$ of the groundwater, the high concentrations for these elements trace are most likely due to presence of colloidal particles. As the groundwater are oxidizing, solubility of $\mathrm{Fe}, \mathrm{Al}$, and $\mathrm{Mn}$ oxides is low and concentrations of dissolved $\mathrm{Fe}, \mathrm{Al}$, and $\mathrm{Mn}$ are, therefore, mostly low.

The processes of dissolution and release from oxides and oxyhydroxides, mainly $\mathrm{Al}, \mathrm{Mn}$, and $\mathrm{Fe}$, control the presence 


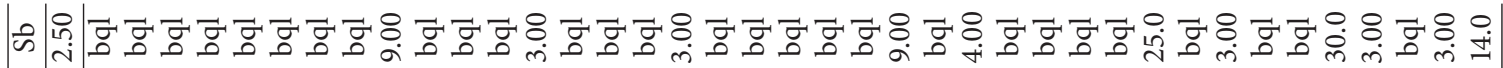

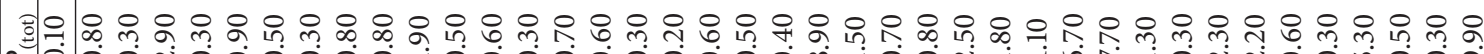

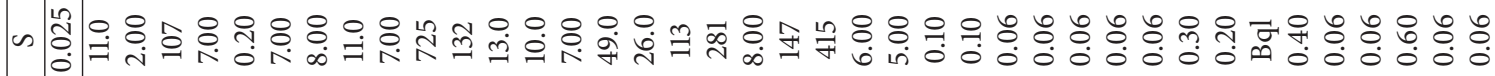

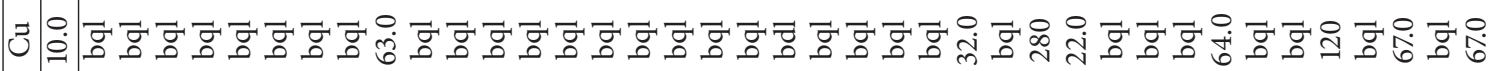

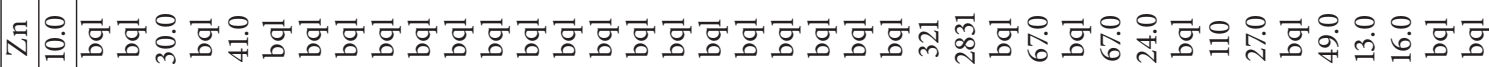

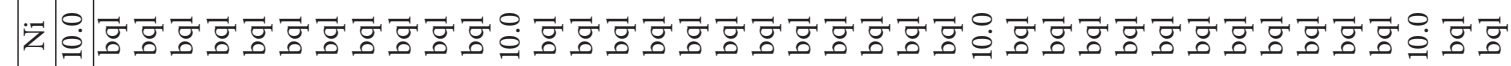

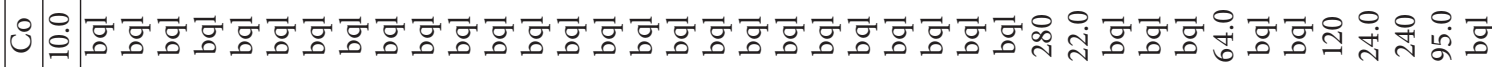

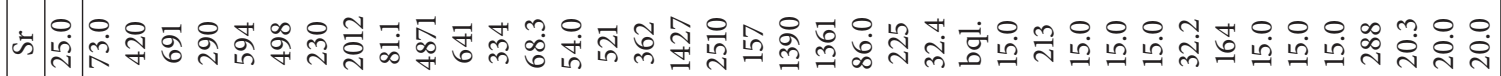
उ \&

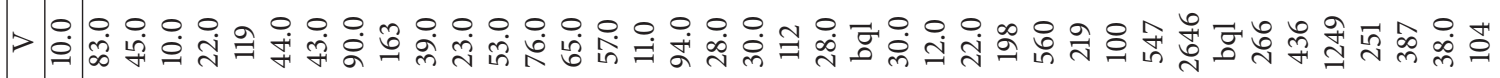

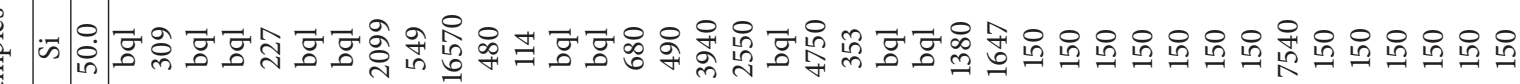

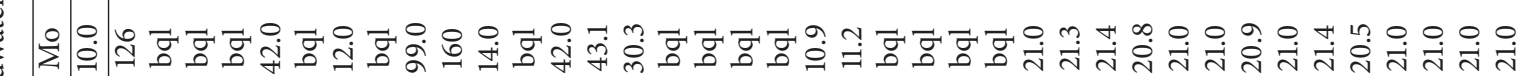

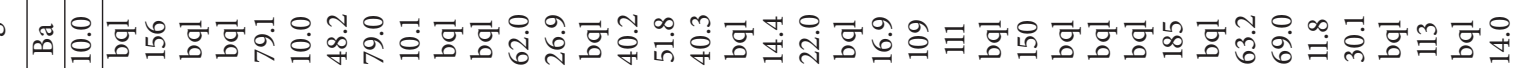

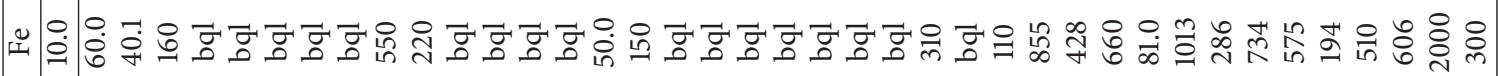
४

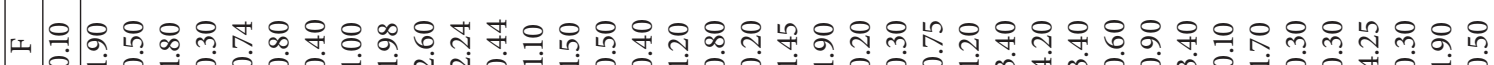

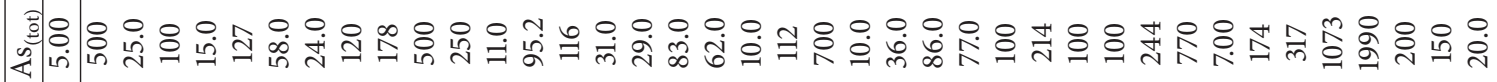
A

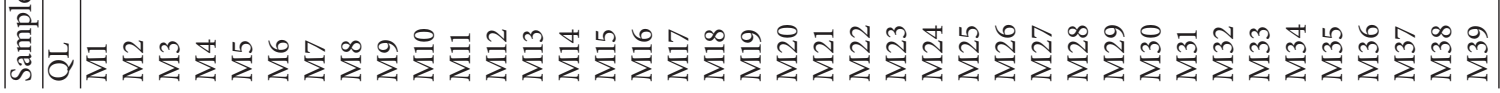




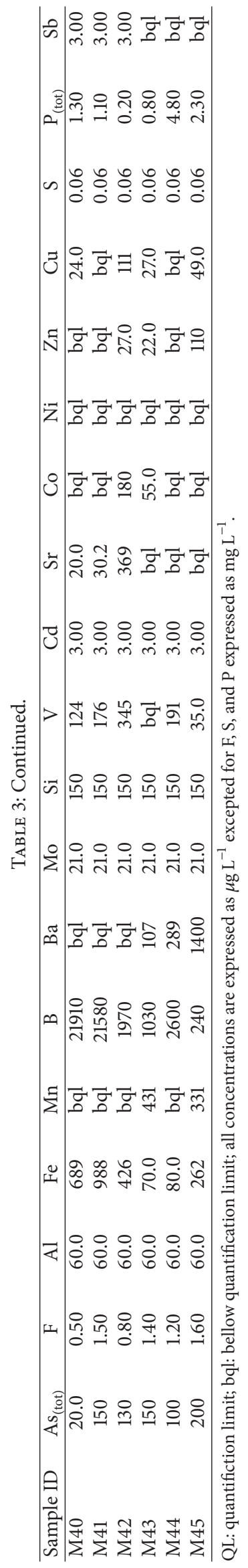


TABLE 4: Risk-based drinking water criteria and the percentage of groundwater samples exceeding these criteria.

\begin{tabular}{|c|c|c|c|c|}
\hline \multirow[t]{2}{*}{ Element } & \multicolumn{2}{|c|}{$\begin{array}{l}\text { Risk-based drinking } \\
\text { water criteria }\end{array}$} & \multicolumn{2}{|c|}{$\begin{array}{l}\text { Percentage of } \\
\text { groundwater } \\
\text { samples exceeding } \\
\text { these criteria }\end{array}$} \\
\hline & $\mathrm{WHO}^{*}$ & $\mathrm{CAA}^{* *}$ & WHO & CAA \\
\hline As $\left(\mu g \mathrm{~L}^{-1}\right)$ & $10^{* * *}$ & 50 & 91 & 73 \\
\hline $\mathrm{Al}\left(\mu \mathrm{g} \mathrm{L}^{-1}\right)$ & $\begin{array}{l}\text { not } \\
\text { established }\end{array}$ & 200 & NA & 16 \\
\hline $\mathrm{B}\left(\mu \mathrm{g} \mathrm{L}^{-1}\right)$ & 2400 & 500 & 78 & 78 \\
\hline $\mathrm{Ba}\left(\mu \mathrm{g} \mathrm{L}^{-1}\right)$ & 700 & None & 2 & NA \\
\hline $\mathrm{Cd}\left(\mu \mathrm{g} \mathrm{L}^{-1}\right)$ & 3 & 5 & 13 & 2 \\
\hline $\operatorname{Cr}\left(\mu \mathrm{g} \mathrm{L}^{-1}\right)$ & $50^{* * *}$ & 50 & 0 & 0 \\
\hline $\mathrm{Cu}\left(\mu \mathrm{gL}^{-1}\right)$ & 2000 & 1000 & 0 & 0 \\
\hline Fe total $\left(\mu \mathrm{g} \mathrm{L}^{-1}\right)$ & $\begin{array}{c}\text { not } \\
\text { established }\end{array}$ & 300 & NA & 31 \\
\hline $\mathrm{F}\left(\mathrm{mg} \mathrm{L}^{-1}\right)$ & 1.50 & 1.00 & 31 & 47 \\
\hline $\operatorname{Mn}\left(\mu \mathrm{gL}^{-1}\right)$ & $\begin{array}{c}\text { not } \\
\text { established }\end{array}$ & 100 & NA & 16 \\
\hline $\mathrm{Ni}\left(\mu \mathrm{g} \mathrm{L}^{-1}\right)$ & 70 & 20 & 0 & 0 \\
\hline $\mathrm{Pb}\left(\mu \mathrm{g} \mathrm{L}^{-1}\right)$ & $10^{* * *}$ & 50 & 0 & 0 \\
\hline $\mathrm{Sb}\left(\mu \mathrm{g} \mathrm{L}^{-1}\right)$ & 20 & 20 & 4.5 & 4.5 \\
\hline $\operatorname{Se}\left(\mu \mathrm{g} \mathrm{L}^{-1}\right)$ & $10^{* * *}$ & 10 & 0 & 0 \\
\hline $\mathrm{Zn}\left(\mu \mathrm{g} \mathrm{L}^{-1}\right)$ & $\begin{array}{c}\text { not } \\
\text { established }\end{array}$ & 5000 & NA & 0 \\
\hline
\end{tabular}

NA: not applicable.

*WHO: World Health Organization, have not established risk-based drinking water criteria for $\mathrm{Al}, \mathrm{Ag}, \mathrm{Be}, \mathrm{Bi}, \mathrm{Co}, \mathrm{Fe}, \mathrm{Mn}, \mathrm{Mo}, \mathrm{Si}, \mathrm{Sr}, \mathrm{Ti}, \mathrm{V}$, and $\mathrm{Zn}$. **CAA: Código Alimentario Argentino.

*** Provisional guideline value.

and mobility of As and F in groundwater [1]. Kim et al. [35] suggested that the cocontamination of As and F observed in oxidizing aquifers in many countries is associated with the desorption from the $\mathrm{Fe}$-(hydr) oxides by the $\mathrm{pH}$ increases. The correlations between As and $\mathrm{F}$ are generally very high in those aquifers because the As released from Fe-(hydr) oxides does not readily precipitate again in the oxidizing alkaline condition. This is consistent with our observations, as many of the samples show high $\mathrm{pH}$ values and moderate coefficient correlation value between As and $\mathrm{F}\left(r^{2}=0.50\right)$. Also, solubility of Al minerals may be enhanced by the complex of dissolved $\mathrm{Al}$ with $\mathrm{F}$ that is also released from volcanic glasses.

Vanadium in groundwater ranged between $<10.0$ (QL) and $2646 \mu \mathrm{g} \mathrm{L}^{-1}$. The highest $\mathrm{V}$ concentration was found in sample M31 (Table 2). Vanadium shows a moderated positive correlation with As $\left(r^{2}=0.42\right)$ and is likely to be derived from similar mineral sources (secondary Fe and Mn oxides) under the high $\mathrm{pH}$ conditions [1]. Our results also indicate that Mo in general appears in low concentrations (Table 3). Molybdenum is weakly correlated with As $\left(r^{2}=0.20\right)$.

Gomez et al. [27] suggest that V, U, B, and Mo are enriched in volcanic materials and are mobilized as vanadate, molybdate, borate, and so forth, under oxidizing conditions. Alternatively, they are mobilized in alkaline solutions under conditions of high $\mathrm{pH}$ and high $\mathrm{HCO}_{3}{ }^{-}$, controlled by carbonate reactions, (e.g., the $\mathrm{F}$ may be forming anionic complexes with $\mathrm{B}, \mathrm{Fe}$, and $\mathrm{Al}$ ).

Antimony (Sb) is ubiquity a Group V of the periodic table and is similar to As in aspects as chemical behavior and toxicity to animals [5]. The $\mathrm{Sb}$ concentrations in studied samples exceeded $20 \mu \mathrm{g} \mathrm{L}{ }^{-1}$, WHO and CAA drinking water guideline values in $4.5 \%(2 / 45)$ of the analyzed samples (Tables 3 and 4).

Cadmium reaches a maximum of $7.0 \mu \mathrm{g} \mathrm{L}^{-1}$ with most samples being less than $3.0 \mu \mathrm{g} \mathrm{L}^{-1}$. As this element forms cationic species in solution, its mobilization is not favored under the alkaline conditions of the groundwater [1].

The presence of arsenic and heavy metals in the samples collected from this region of Chaco in Argentina may be due to local geochemical conditions that facilitate the transfer of naturally occurring arsenic from soil and sediment to the water. The people in the Comandante Fernández Department may be overexposed not only to As, but also to B, Cd, Mn, and F. Adverse health effects may appear in coming years. This problem is a serious concern for the local population.

\section{Conclusions}

The results of the current study indicate that approximately $91 \%$ of the groundwater samples used for consumption by human and livestock, from the Comandante Fernández Department (Chaco province, Argentina), exceed the WHO provisional guideline value of $10 \mu \mathrm{g} \mathrm{L}^{-1}$ As, recommended as a maximum allowable level in potable water.

Evaporation, potentiated in arid, and semiarid zone, favors the increase of salinity and alkalinity, the results is a low quality of the resource but is not conditioning the concentration of As and F. Hence, factors other than evaporation, such as desorption from metal oxides and possibly silicate reaction, could be likely controlling As and F mobilization. Furthermore arsenic, associated trace elements may be absorbed on the surface of iron and aluminum oxides and oxyhydroxides (hematite, goethite, $\mathrm{Fe}(\mathrm{OH})_{3}$, and gibbsite), limiting the mobility of trace elements. Groundwater with high $\mathrm{pH}$ values and high concentration of bicarbonate would facilitate the dissolution of volcanic glass; thus, trace elements may enter groundwater cycles, forming anionic complexes in alkaline solutions and acquiring great mobility.

The hydrochemical trace in the region is characterized by high salinity and high As and F concentrations, which is related to volcanism and hydrothermal activity from the Andes. This association is often linked to presence of $\mathrm{B}$, $\mathrm{Cd}, \mathrm{Mo}, \mathrm{Mn}$, and $\mathrm{V}$, indicating their common origin in the volcanic glasses.

Due to high As concentrations found in groundwater, serious health risk must be considered. The population in the area may be exposed to the chronic toxicological effects of hydro arsenicism and fluorosis, increasing the risks of contracting other diseases derived from them. Since the groundwater studied here constitutes the principal source of drinking water in the zone, mitigation efforts should not be limited to As health risks from other toxic elements present in drinking water must also be addressed in this region. 


\section{Conflict of Interest}

The authors declare that there is no conflict of interests regarding the publication of this paper. Its publication is approved by all authors and tacitly or explicitly by the responsible authorities where the work was carried out, and that, if accepted, it will not be published elsewhere in the same form, in English or in any other language, including electronically without the written consent of the copyright-holder.

\section{Acknowledgments}

This work was supported with funds from PI 36/00005 Universidad Nacional del Chaco Austral (UNCAus). Patricia S. Blanes thanks the National Academy of Exact, Physic and Natural Sciences for granting a Ph.D. fellowship.

\section{References}

[1] P. L. Smedley, H. B. Nicolli, D. M. J. Macdonald, A. J. Barros, and J. O. Tullio, "Hydrogeochemistry of arsenic and other inorganic constituents in groundwaters from La Pampa, Argentina," Applied Geochemistry, vol. 17, no. 3, pp. 259-284, 2002.

[2] S. Muhammad, M. T. Shah, and S. Khan, "Health risk assessment of heavy metals and their source apportionment in drinking water of Kohistan region, northern Pakistan," Microchemical Journal, vol. 98, no. 2, pp. 334-343, 2011.

[3] S. S. Farías, V. A. Casa, C. Vázquez, L. Ferpozzi, G. N. Pucci, and I. M. Cohen, "Natural contamination with arsenic and other trace elements in ground waters of Argentine Pampean Plain," Science of the Total Environment, vol. 309, no. 1-3, pp. 187-199, 2003.

[4] L. Järup, "Hazards of heavy metal contamination," British Medical Bulletin, vol. 68, pp. 167-182, 2003.

[5] World Health Organization (WHO), "Recommendations," in Guidelines for Drinking Water Quality, vol. 1, Geneva, Switzerland, 4th edition, 2011.

[6] C. Hopenhayn, "Arsenic in drinking water: impact on human health," Elements, vol. 2, no. 2, pp. 103-107, 2006.

[7] S. H. Lamm and M. B. Kruse, "Arsenic ingestion and bladder cancer mortality-what do the dose-response relationships suggest about mechanism?" Human and Ecological Risk Assessment, vol. 11, no. 2, pp. 433-450, 2005.

[8] C.-H. Wang, C. K. Hsiao, C.-L. Chen et al., "A review of the epidemiologic literature on the role of environmental arsenic exposure and cardiovascular diseases," Toxicology and Applied Pharmacology, vol. 222, no. 3, pp. 315-326, 2007.

[9] J. Bundschuh, M. I. Litter, F. Parvez et al., "One century of arsenic exposure in Latin America: a review of history and occurrence from 14 countries," Science of the Total Environment, vol. 429, pp. 2-35, 2012.

[10] M. T. Alarcón-Herrera, J. Bundschuh, B. Nath et al., "Cooccurrence of arsenic and fluoride in groundwater of semi-arid regions in Latin America: genesis, mobility and remediation," Journal of Hazardous Materials, 2012.

[11] E. E. Buchhamer, P. S. Blanes, R. M. Osicka, and M. C. Giménez, "Environmental risk assessment of arsenic and fluoride in the chaco province, argentina: research advances," Journal of Toxicology and Environmental Health A, vol. 75, no. 22-23, pp. 14371450, 2012.
[12] A. Cabrera, M. Blarasin, E. Matteoda, G. Villalva, and M. L. Gómez, "Composición química del agua subterránea en el sur de Córdoba: línea de base hidroquímica o fondo natural en referencia a arsénico y flúor," in Aguas Superficiales y Subterráneas en el sur ae Córdoba: Una Perspectiva Geoambiental, M. Blarasin, S. Degiovanni, A. Cabera, and M. Villegas, Eds., pp. 81-90, Universidad Nacional de Río Cuarto, Río Cuarto, Argentina, 2005.

[13] P. Bhattacharya, M. Claesson, J. Bundschuh et al., "Distribution and mobility of arsenic in the Río Dulce alluvial aquifers in Santiago del Estero Province, Argentina," Science of the Total Environment, vol. 358, no. 1-3, pp. 97-120, 2006.

[14] B. Nicolli, O. C. Tujchneider, M. C. Paris, M. Blanco, and A. J. Barros, "Movilidad del arsénico y oligoelementos asociados en aguas subterráneas del centro-norte de la provincia de Santa Fe, Argentina," in Proceedings of the Presencia de Flúor y Arsénico en Aguas Subterráneas, VI Congreso Hidrogeológico Argentino, G. Galindo, J. L. Fernández Turiel, and A. Storniolo, Eds., pp. 81-90, Santa Rosa La Pampa, Argentina, 2009.

[15] H. B. Nicolli, A. Tineo, J. W. García, C. M. Falcón, and P. L. Smedley, "Mobilization of arsenic and other trace element of health concern in groundwater from the Salí River Basin, Tucumán Province, Argentina," Environmental Geochemistry and Health, vol. 34, no. 2, pp. 251-262, 2012.

[16] R. M. Osicka, N. Agulló, C. Herrera Ahuad, and M. C. Giménez, "Evaluación de las concentraciones de fluoruro y arsénico en las aguas subterráneas del Domo Central de la provincia del Chaco," Comunicaciones Científicas y Tecnológicas. Universidad Nacional del Nordeste, 2002, http://www.unne.edu.ar/ unnevieja/Web/cyt/cyt/2002/08-Exactas/E-049.pdf.

[17] C. E. Fiorentino, J. D. Paoloni, M. E. Sequeira, and P. Arosteguy, "The presence of vanadium in groundwater of southeastern extreme the pampean region Argentina. Relationship with other chemical elements," Journal of Contaminant Hydrology, vol. 93, no. 1-4, pp. 122-129, 2007.

[18] P. Sprechmann, F. G. Aceñaloza, C. Gaucher, A. C. R. Nogueira, and M. J. Perez, "Trasgresión Paranaense: paleoestuario del tethys del mioceno medio y/o superior en Sudamérica," in Congreso Latinoamericano de Geología, Montevideo-Uruguay, Abstracts, 1 CDRoom, pp. 10-15, Sociedad Latinoamericana de Geología, 2001.

[19] F. Larroza and L. S. Fariña, “Caracterización hidrogeológica del sistema acuífero Yrenda (SAY) en Paraguay: recurso compartido con y Bolivia," in Proceedings of the IV Congreso Argentino de Hidrogeología, TOMO II, Argentinarío Cuarto, Córdoba, Argentina, 2005.

[20] E. Popolizio, P. Y. Serra, and G. O. Hort, "La clasificación taxonómica del Chaco," Centro de Geociencia Aplicada, vol. 3, no. 1, pp. 11-32, 1980.

[21] INTA, "Instituto Nacional de Tecnología Agropecuaria," Agrometeorología, http://www.inta.gov.ar/saenzpe/meteorologia/meteorologia.htm.

[22] M. G. García, O. Sracek, D. S. Fernández, and M. D. V. Hidalgo, "Factors affecting arsenic concentration in groundwaters from Northwestern Chaco-Pampean Plain, Argentina," Environmental Geology, vol. 52, no. 7, pp. 1261-1275, 2007.

[23] US Environmental Protection Agency ( EPA), "Arsenic, Inorganic. United States Environmental Protection Agency, Integrated Risk Information System (IRIS), (CASRN, 7440-38-2)," 1998, http://www.epa.gov/iris/subst/0278.htm. 
[24] Comisión Nacional de Alimentos (CONAL) Acta $\mathrm{N}^{2}$ 93, Reunión Ordinaria 30/11 y 01/12-/2011 (Prórroga Art. 982 y 983 del CAA).

[25] CAA, (Código Alimentario Argentino). Cap XII: Bebidas hídricas, agua y agua gasificada. In Código Alimentario Argentino, modificatoria del Art. 982. (Res. 68/2007 y 196/2007) Ley 18. 284, Buenos Aires, Argentina, 2007, http://www.anmat.gov .ar/CODIGOA/Capitulo_XII_Agua_2007-05.pdf.

[26] J. L. Fernández Turiel, G. Galindo, M. A. Parada, D. Gimeno, M. García-Vallés, and J. Saavedra, "Estado actual del conocimiento sobre el arsénico en el agua de Argentina y Chile: origen, movilidad y transporte," in Arsénico en Agua: Origen, movilidad y tratamiento, II Seminario Hispano-Latinoamericano sobre Temas Actuales de Hidrología Subterránea y IV Congreso Hidrogeológico Argentino, pp. 1-22, Río Cuarto, Argentina, 2005.

[27] M. L. Gomez, M. T. Blarasin, and D. E. Martínez, "Arsenic and fluoride in a loess aquifer in the central area of Argentina," Environmental Geology, vol. 57, no. 1, pp. 143-155, 2009.

[28] P. L. Smedley, D. G. Kinniburgh, D. M. J. Macdonald et al., "Arsenic associations in sediments from the loess aquifer of $\mathrm{La}$ Pampa, Argentina," Applied Geochemistry, vol. 20, no. 5, pp. 989-1016, 2005.

[29] D. L. Ozsvath, "Fluoride and environmental health: a review," Reviews in Environmental Science and Biotechnology, vol. 8, no. 1, pp. 59-79, 2009.

[30] E. M. Farfán Torres, P. M. Naranjo, A. Boemo, I. Lomniczi, and L. Lorenzo, "Distribution of arsenic in groundwater in the Chaco Salteño, Argentina," in Workshop on as Distribution in Ibero-America, M. I. Litter, Ed., CyTED IBEROARSEN Abstract Book, pp. 57-60, 2006.

[31] http://www.jctonic.com/include/minerals/boron.htm.

[32] M. A. Halim, R. K. Majumder, S. A. Nessa et al., "Evaluation of processes controlling the geochemical constituents in deep groundwater in Bangladesh: spatial variability on arsenic and boron enrichment," Journal of Hazardous Materials, vol. 180, no. $1-3$, pp. 50-62, 2010.

[33] J. Buschmann, M. Berg, C. Stengel, and M. L. Sampson, "Arsenic and manganese contamination of drinking water resources in Cambodia: coincidence of risk areas with low relief topography," Environmental Science and Technology, vol. 41, no. 7, pp. 21462152, 2007.

[34] R. A. Beckman, A. S. Mildvan, and L. A. Loeb, "On the fidelity of DNA replication: manganese mutagenesis in vitro," Biochemistry, vol. 24, no. 21, pp. 5810-5817, 1985.

[35] S.-H. Kim, K. Kim, K.-S. Ko, Y. Kim, and K.-S. Lee, “Co-contamination of arsenic and fluoride in the groundwater of unconsolidated aquifers under reducing environments," Chemosphere, vol. 87, no. 8, pp. 851-856, 2012. 

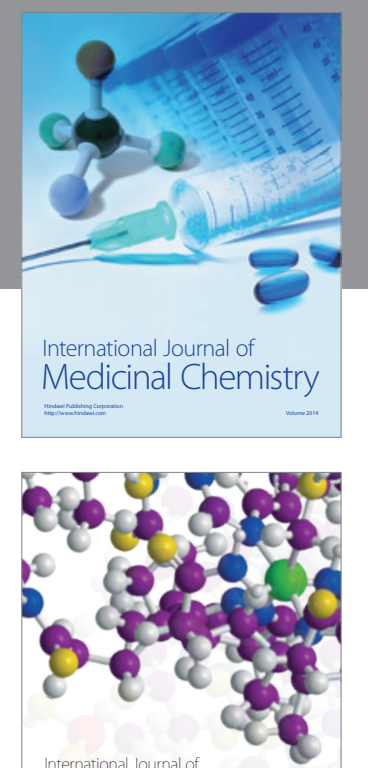

\section{Carbohydrate} Chemistry

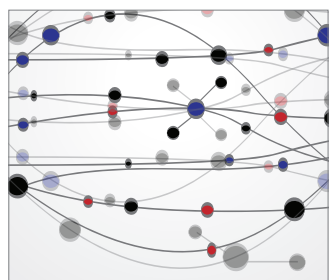

The Scientific World Journal
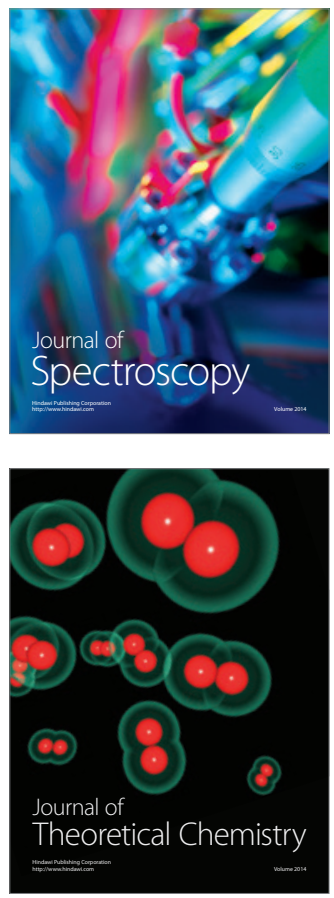
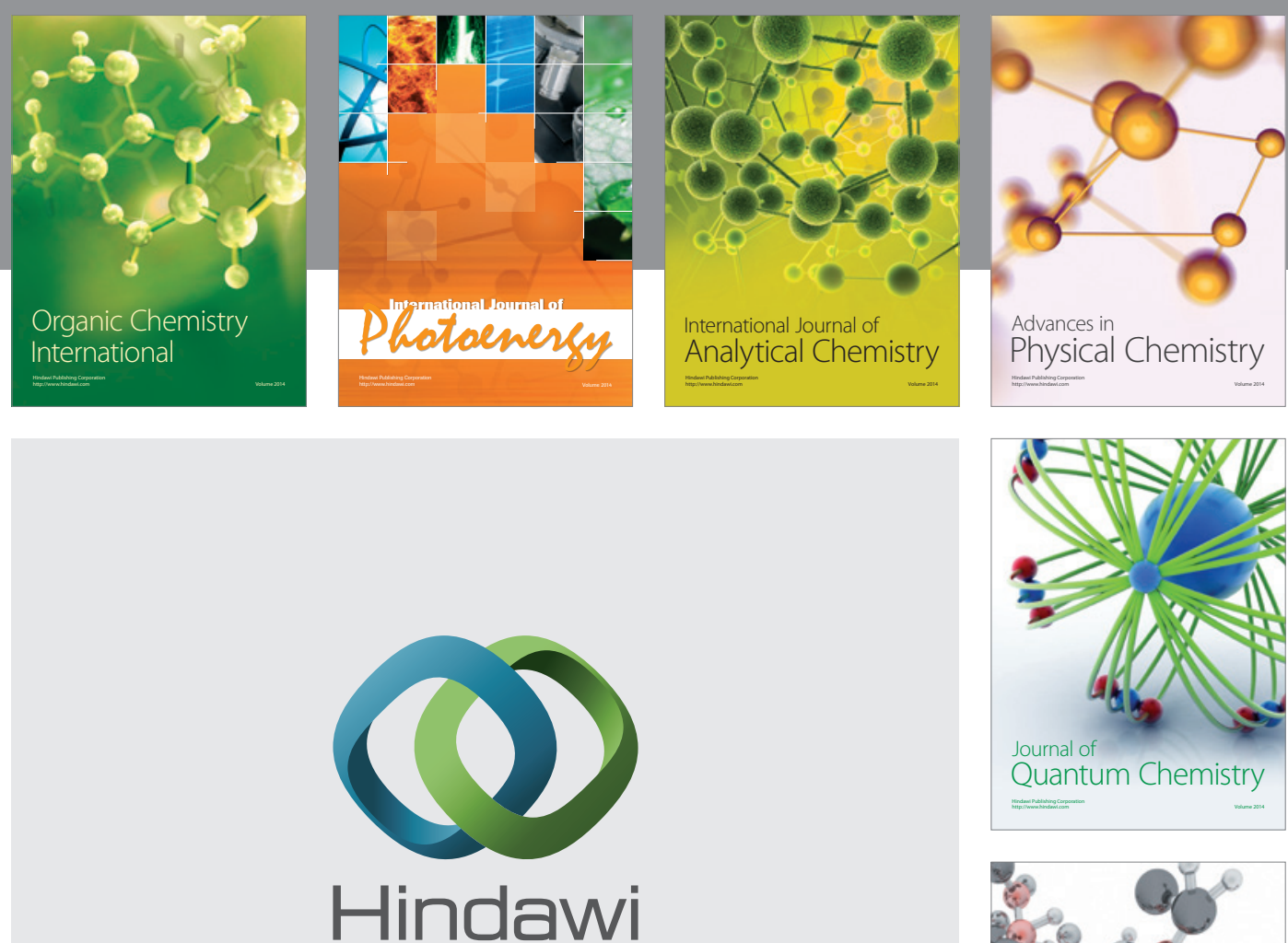

Submit your manuscripts at

http://www.hindawi.com

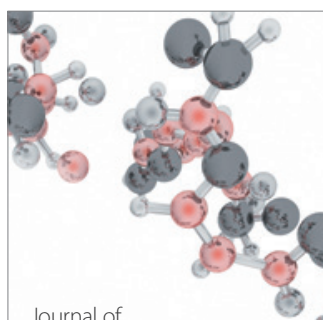

Analytical Methods

in Chemistry

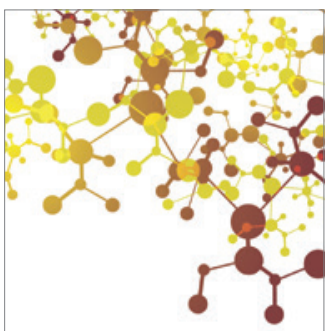

Journal of

Applied Chemistry

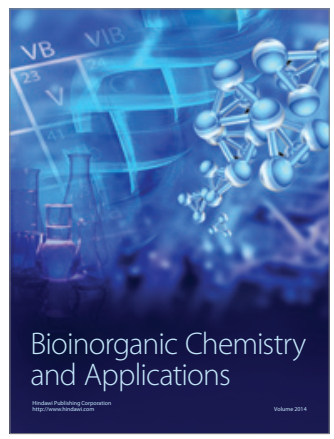

Inorganic Chemistry
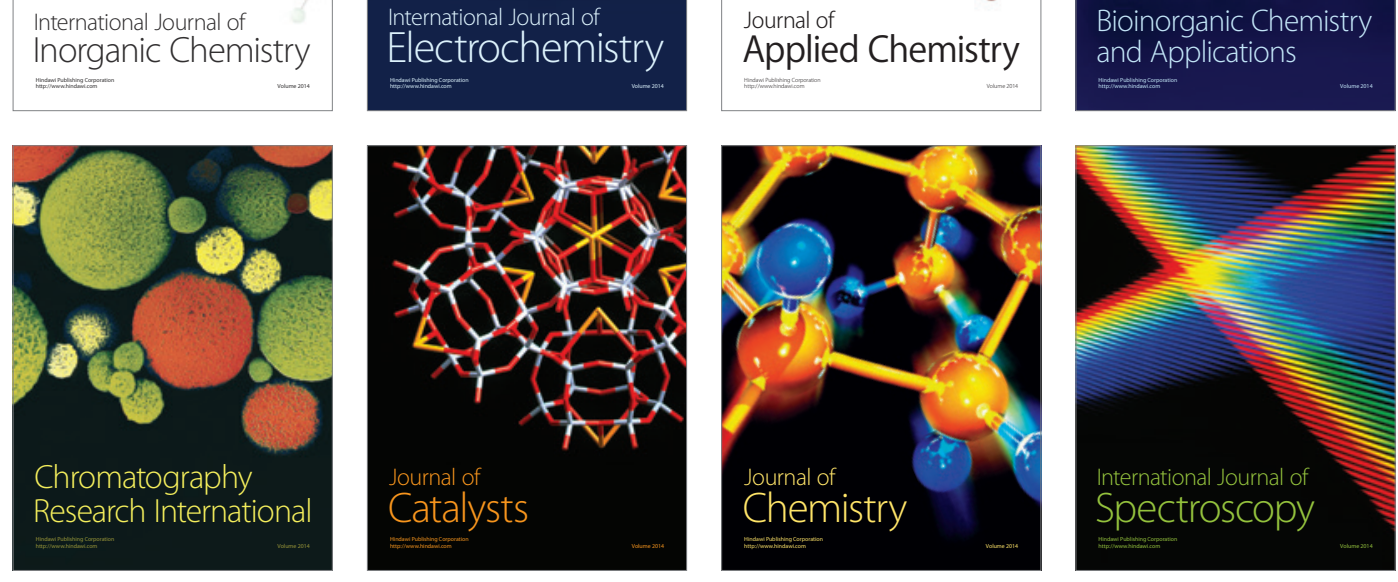